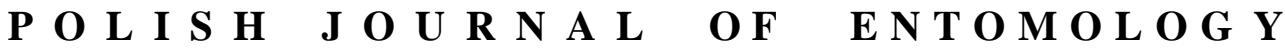

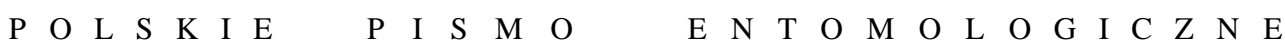

VOL. 84: 3-7

Lublin

30 April 2015

DOI: $10.1515 /$ pjen-2015-0001

\section{Protarchanara brevilinea FenN, 1864 - a moth species new to Poland (Lepidoptera: Noctuidae)}

\section{JANUSZ NOWACKI, ROMAN WĄSALA}
Department of Entomology and Environmental Protection, Poznań University of Life Sciences, ul. Dąbrowskiego 159, 60-594 Poznań, e-mail: jnowacki@up.poznan.pl, rwasala@up.poznan.pl

\begin{abstract}
This is the first record of Protarchanara brevilinea (Lepidoptera, Noctuidae) from Poland. It was found in Western Pomerania, NW Poland.
\end{abstract}

KEY WORDS: Lepidoptera: Noctuidae, Protarchanara brevilinea, new record, Poland.

\section{INTRODUCTION}

For a long time Protarchanara brevilinea FENN, 1864, which belongs to the Apameini tribe, was classified in the genus Photedes LEDERER, 1857 (POOLE 1989). Owing to the significant differences between the male and female reproductive organs of $P$. brevilinea and the other representatives of Photedes sp., however, a new genus Protarchanara BECK, 1999, was set up for the single species of P. brevilinea. Subsequently, Protarchanara abrupta (EVERSMANN, 1854), a Middle-Palaearctic species, was also incorporated into the genus (ZILLI et al. 2005)

Protarchanara brevilinea is a species with a Euro-Siberian range. In Europe it has a disjunct distribution, occurring in two widely separated areas: a north-western one, demonstrating a typical Atlantic range, and a south-eastern area, extending from Crimea across the steppes of southern Russia to the Caspian Sea coast (SINEV et al. 2008). In the Atlantic region $P$. brevilinea occurs at an isolated site in western France and along North Sea coasts in England, Holland, Denmark and Germany. It is also found along the Baltic coasts of Denmark, Germany and southern Sweden, and in the east in southern Finland, 
Russia, Estonia, Latvia and Lithuania (Fig. 1) (KARSHOlt \& NiELSEN 1998, SAVENKOV et al. 1996, SinEV et al. 2008, SKOU 1991, VIIDALEPP 1995).

In central Europe the species has so far been reported only from northern Germany and Lithuania, where it is mostly local and scarce (NOWACKI 1998). Hence, its range along the Baltic coast (Fig. 1) was discontinuous given the lack of reports of this species from Poland (BUSZKO, NOWACKI 2000), which, despite many attempts to find it had not been confirmed earlier (NOWACKI 1994). Outside Europe P. brevilinea has a very local range in a narrow strip from the northern Caucasus through western Siberia, from the shores of Lake Baikal to the Amur valley and in the Primorsky and Khabarovsky Regions, where it reaches the Pacific coast (KONONENKO 2005). It has also been reported from Japan (INOUE et al. 1982).

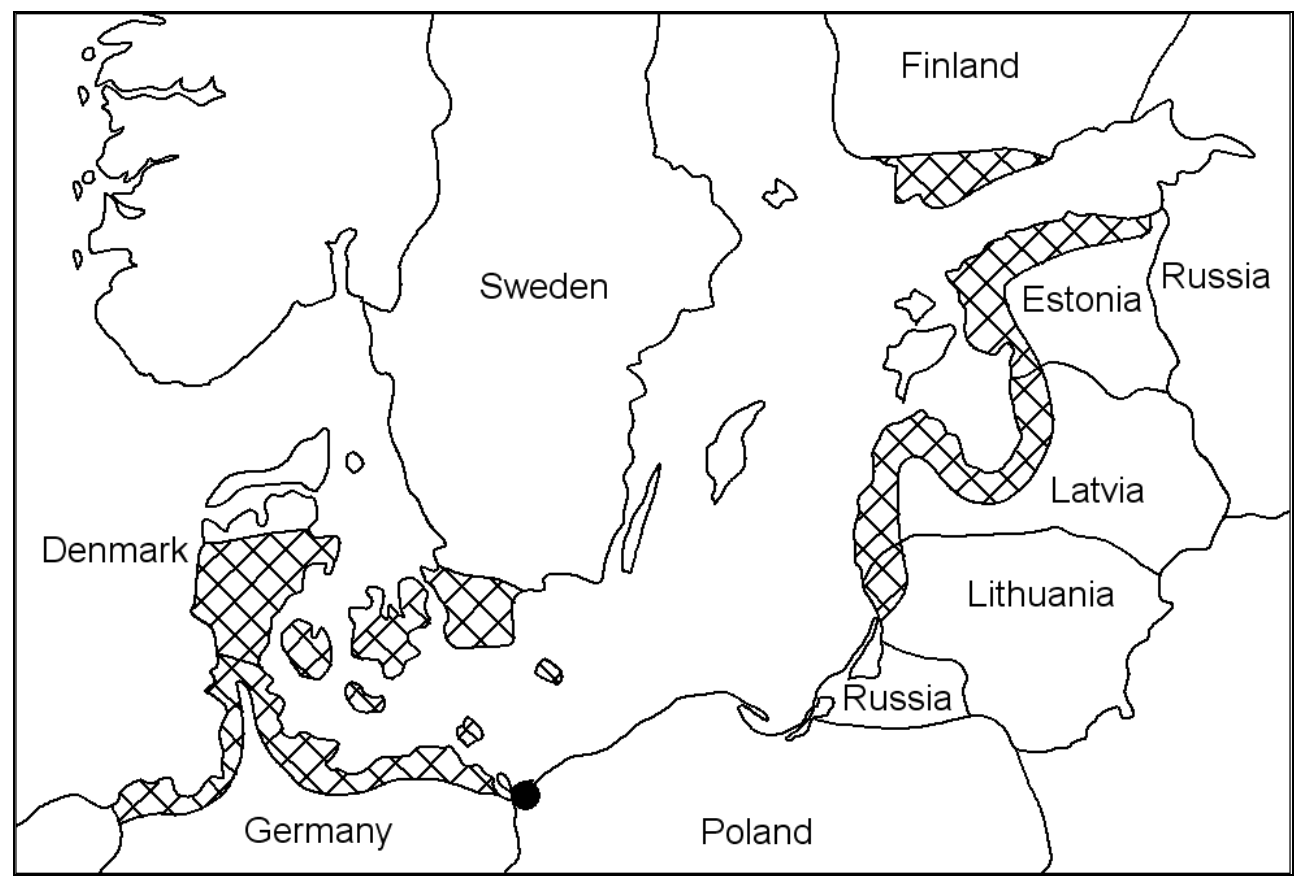

Fig. 1. Distribution of Protarchanara brevilinea in the Baltic Region.

\section{MATERIAL AND METHODS}

Based on the range of $P$. brevilinea known so far along the Baltic coast, it was hypothesised that the species should also occur in Poland. For many years light and bait traps were set up in habitats potentially suitable for the species. 


\section{RESULTS}

As part of a study of moths in north-western Poland, i.e. the province of Western Pomerania, Protarchanara brevilinea was caught in a light trap at one site: ŚwinoujścieKarsibór 28 VII 2013, 2 VIII 2014, UTM: VV56, 2exx. R. WĄSALA leg. (Figs 2-4). The study site is shown on the Fig. 5 .

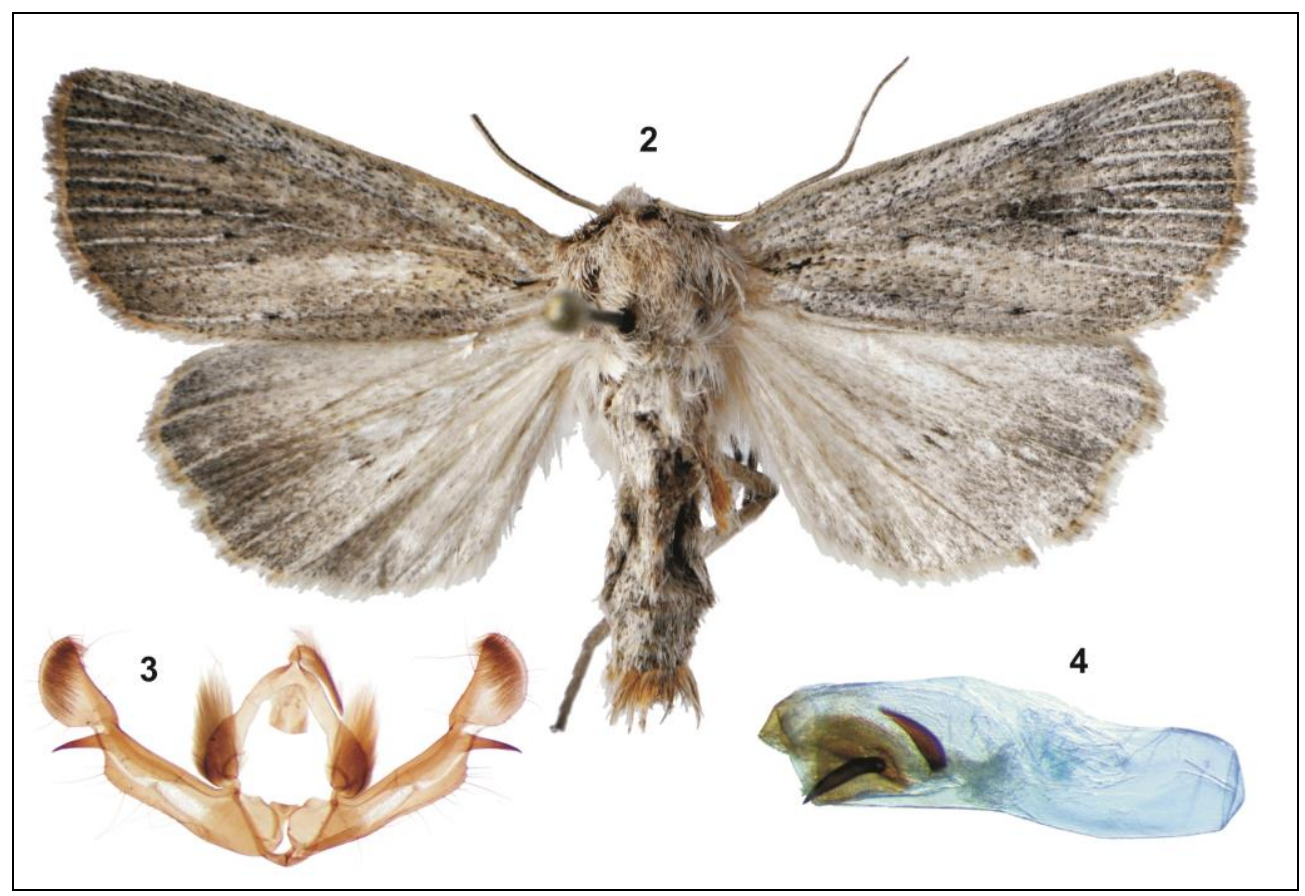

Figs 2-4. Protarchanara brevilinea - Poland, Świnoujście-Karsibór, 28 VII 2013, leg. R. WĄSALA: 2 - imago; 3 - male genitalia; 4 - aedeagus.

\section{DISCUSSION}

The Polish specimen of P. brevilinea was caught in a Phragmitetum australis reed bed. This corroborates previous information that the species is found in this type of reed bed, where Common Reed Phragmites australis (CAVAnILles) Trinius ex STEUdel, 1841 occurs mainly on the sandy shores of coastal lagoons beyond the range of the water for the most of the year (AHOLA \& SiLVONEN 2008, SKou 1991). Adult moths appear in one 


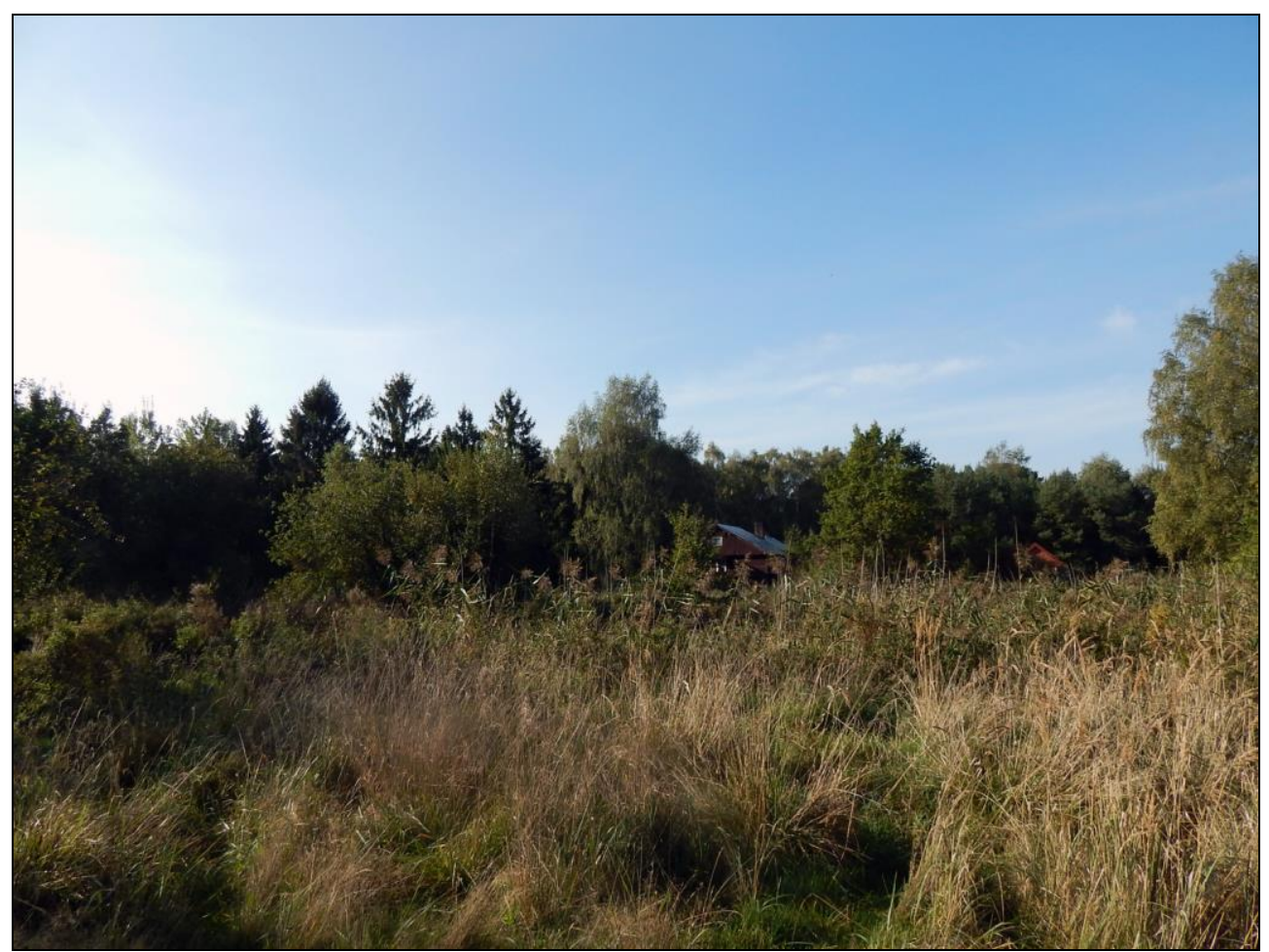

Fig. 5. The site of catch of Protarchanara brevilinea in Świnoujście-Karsibór (Poland).

generation from mid-July to mid-August. Females lay eggs which overwinter on Common Reed. The larvae grow from spring until the end of the June, seeking food within the common reed and while seeking food they are frequently seeking the host plant. Pupation occurs on the ground, near the food plant and the pupa is protected within a delicate case (AHOLA \& SILVONEN 2008).

The finding of $P$. brevilinea in Poland is a very important discovery, as it confirms the continuity of the species' range along the southern coast of the Baltic. Moreover, taking into consideration the ecological nature of the Polish Baltic coast, one can assume that the species will be reported from other sites there in the future.

\section{REFERENCES}

Ahola M., Silvonen K. 2008. Larvae of Northern European Noctuidae. Vol. 2: Rearing and breeding. Apollo Books, Svendvorg. 
Buszko J., Nowacki J. 2000. The Lepidoptera of Poland. A Distributional Checklist. Polish Entomological Monographs Vol. 1. Polskie Towarzystwo Entomologiczne, Poznań - Toruń.

Inoue H., Sugi S., Kuroko H., Moriuti S., Kawabe A. 1982. Moths of Japan. Vol. 2: Plates and Synonymic catalogue. Kodansha Co. Ltd, Tokyo.

Karsholt O., Stadel Nielsen P. 1998. Revised catalogue of the Lepidoptera of Denmark. Lepidopterologisk Forening, København. [in Danish]

KonONENKo V.S. 2005. Noctuidae Sibiricae, Vol. 1. An annotated check list of the Noctuidae (s. 1.) (Insecta, Lepidoptera) of the Asian part of Russia and the Ural Region. Entomological Press, Soro.

NOWACKI J. 1994. Structure of distribution ranges of noctuid moths (Lepidoptera, Noctuidae) in the coastal dune belt of Polish Baltic Shore. Wiadomości Entomologiczne 12 (Suppl.): 1-127. [in Polish]

NowACKI J. 1998. The Noctuids (Lepidoptera, Noctuidae) of Central Europe. Coronet Books, Bratislava.

Poole R.W. 1989. Lepidopterorum Catalogus. Fasc. 118, Noctuidae. E.J. Brill Flora \& Fauna Publications, Leiden, New York, København, Köln.

SAVEnKov N., Šulcs I., KeRpola S., Huldèn L. 1996. Checklist of Latvian Lepidoptera. Baptria 21 (3a): $1-71$.

SKOU P. 1991. Handbook of the Noctuidae and Herminiidae of Denmark, Norway, Sweden, Finland and Iceland. Apollo Books, Stenstrup. [in Danish]

SineV Y. (ed.) 2008. Catalogue of the Lepidoptera of Russia. Scientific Press, Sankt Petersburg.

VIIDALEPP K.J. 1995. Catalogus Macrolepidopterorum Estoniae. Teaduste Akadeemia Kirjastus, Tallinn-Tartu.

Zilli A., Ronkay L., Fibiger M. 2005. Noctuidae Europaeae, Vol. 8. Apameini. Entomological Press, Soro.

Received: 2 October 2014

Accepted: 15 December 2014 